NBER WORKING PAPER SERIES

\title{
DEPOSIT INSURANCE AROUND THE GLOBE: WHERE DOES IT WORK?
}

\author{
Edward J. Kane \\ Asli Demirguc-Kunt \\ Working Paper 8493 \\ http://www.nber.org/papers/w8493
NATIONAL BUREAU OF ECONOMIC RESEARCH
1050 Massachusetts Avenue
Cambridge, MA 02138
September 2001

We would like to thank Thorsten Beck, Jerry Caprio, Stijn Claessens, Ross Levine and Rick Mishkin for valuable discussions. The findings, interpretations, and conclusions expressed in this paper are entirely those of the authors. The views expressed herein are those of the authors and not necessarily those of the National Bureau of Economic Research, the World Bank, its Executive Directors, or the countries they represent..

(C) 2001 by Edward J. Kane and Asli Demirguc-Kunt. All rights reserved. Short sections of text, not to exceed two paragraphs, may be quoted without explicit permission provided that full credit, including (C) notice, is given to the source. 
Deposit Insurance Around the Globe: Where Does it Work?

Edward J. Kane and Asli Demirguc-Kunt

NBER Working Paper No. 8493

September 2001

JEL No. G2, F3, K2

\begin{abstract}
$\underline{\text { ABSTRACT }}$
Explicit deposit insurance has been spreading rapidly in recent years, even to countries with low levels of financial and institutional development. Economic theory indicates that deposit-insurance design features interact--for good or ill--with country-specific elements of the financial and governmental contracting environment. This paper documents the extent of cross-country differences in depositinsurance design and reviews empirical evidence on how particular design features affect private market discipline, banking stability, financial development, and the effectiveness of crisis resolution. This evidence challenges the wisdom of encouraging countries to adopt explicit deposit insurance without first stopping to assess and remedy weaknesses in their informational and supervisory environments.
\end{abstract}

Edward J. Kane

Finance Department

Boston College

Chestnut Hill, MA 02467

and NBER

edward.kane@bc.edu
Asli Demirguc-Kunt

The World Bank

1818 H St., NW

Washington, DC 20433 


\section{Introduction}

During the last two decades, a wave of systemic banking crises has rolled back and forth around the globe. The wave has struck developed and developing countries alike, resulting in 112 episodes of systemic crisis in 93 countries and 51 episodes of borderline crisis in 46 countries (Figure 1). ${ }^{1}$

Proliferation of large-scale banking crises is disruptive and costly. Depositors lose access to their funds, good borrowers can lose access to credit and even be forced into bankruptcy, and some sound banks may be driven out of business. Would-be issuers of debt and equity instruments find that markets have dried up. And taxpayers are typically presented with a large bill for mitigating these disruptions. The full costs of these crises go beyond direct fiscal costs to include such consequences as derailed stabilization programs, growth slowdowns and increased poverty. Still, total fiscal costs incurred in the 1997 Thai and Korean crises exceeded 30 percent of GDP, and in Indonesia budgetary costs approached 50 percent of GDP. ${ }^{2}$

When a crisis spreads beyond the banking sector, it triggers a full-fledged financial crisis. The most recent example of this is Turkey where weaknesses in the banking system triggered a crisis of confidence in other domestic financial institutions and led to a large-scale flight of foreign capital and a severe currency crisis.

Both to make systemic breakdowns less likely and to limit the disruption and fiscal costs generated when they occur, in every country policymakers erect a financial safety net. A country's safety net comprises a collection of disruption-mitigating financial policies. These policies include implicit and explicit deposit insurance, lender-

\footnotetext{
${ }^{1}$ See Caprio and Klingebiel (1999) and Mishkin (1996) for a discussion of causes of these crises.
} 
of-last-resort facilities at the central bank, specified procedures for investigating and resolving bank insolvencies, strategies for regulating and supervising banks, and provisions for accessing emergency assistance from multinational institutions such as the IMF.

Among safety net policies, the use of explicit deposit insurance has spread rapidly in recent years. Figure 2 shows that during the last 26 years the number of countries offering explicit deposit insurance guarantees has almost tripled. Establishing a system of explicit deposit insurance guarantees has become a principal feature of policy advice on financial architecture that outside experts give to developing countries (see FolkertsLandau and Lindgren, 1997; and Garcia, 1999). In 1994, deposit insurance was incorporated into the newly created single banking market of the European Union. Today, most OECD countries and an increasing number of developing countries feature some form of explicit depositor protection.

It is not hard to see why explicit deposit insurance schemes appeal to policymakers. In the short run, since no immediate budgetary expenditure needs to be booked, they represent a seemingly costless solution to problems of bank runs or panics. Besides stabilizing the financial sector, an insurance scheme offers political benefits: protecting small depositors and improving opportunities for small banks to compete with larger institutions for deposits.

Mostly dismissed or denigrated by policymakers but long-recognized and persistently emphasized by the academics, is the fact that explicit deposit insurance has the potential to increase bank risk-taking. Because it reduces the incentive of depositors to monitor banks, deposit insurance can encourage excessive risk-taking - i.e., create

\footnotetext{
${ }^{2}$ Total fiscal costs are measured as increases in the stock of public debt relative to GDP in the year if the
} 
moral hazard, and reward imprudent banking practices. But perhaps one of the most persuasive arguments in favor of establishing explicit deposit insurance is that it can be presented as a way to limit the government's commitment to depositors. Lacking coverage limits built into an explicit insurance system, depositors may expect to exert enough political pressure to force taxpayers to supply unlimited deposit guarantees $\underline{\text { ex }}$ post. Such expectations generate moral hazard too.

The U.S. was the first country to introduce a national deposit insurance system. Its goal was to restore confidence in the liquidity of bank deposits rather than to protect small depositors (Golembe, 1960). Indeed, other means of protecting small depositors had long been recognized. For example, in Europe, savings banks maintained liquidity by investing in safe instruments. After decades of debate and largely adverse experience with moral hazard in state-level schemes, federal deposit insurance was enacted in 1933, in the midst of a banking crisis. For the first four decades after its establishment, the absence of failures among large institutions fostered the illusion that deposit insurance is a low cost way of preventing banking crises. But the ripening of the Savings and Loan insurance mess in the 1980s dispelled this illusion, revealing how substantially deposit insurance had exposed taxpayers to loss from risk-taking at insured institutions.

Modern theorists view deposit insurance design as a multiparty principal-agent contracting problem (Kane, 1995; Calomiris, 1996). Contracting parties consist of banks, depositors, supervisors, politicians, and taxpayers. Events that generate losses for insured institutions obligate taxpayers to supply risk capital only when weaknesses in supervisory efforts at loss control allow an institution's losses to surpass the value of its stockholdercontributed net worth. To reduce the chances of future taxpayer losses, authorities in 
developed countries have since agreed to impose risk-based capital standards and to recalibrate these standards when and as regulation-induced innovation undermines their effectiveness. In the U.S., The Federal Deposit Insurance Corporation (FDIC) Improvement Act of 1991 goes even further, imposing on U.S. regulators a duty to act promptly to resolve violations of capital standards. In 1993, Congress offered U.S. taxpayers additional protection by passing the Depositor Preference Act, which in future bank liquidations subordinates the claims of non-deposit creditors to those of the FDIC.

Whether to adopt an explicit deposit insurance system and how to design it depend on the financial and supervisory environment in which it must function. Given the potential trade-off between stability and moral hazard, empirical guidance from crosscountry experience promises to be very useful. Figure 2 indicates that the policymakers are moving ahead at an alarming rate. All too often experts that recommend deposit insurance either assume countries have an appropriate institutional infrastructure or ignore the impact of imperfections in their contracting environments.

Expert advice needs to be grounded in carefully interpreted cross-country empirical evidence. However, an empirical database on which to test policy advice was slow to emerge. A recent World Bank research project developed such a database for researchers worldwide and answered questions about how explicit deposit insurance affects financial stability, how markets discipline bank risk-taking, and the development of the overall financial system. ${ }^{3}$

\footnotetext{
${ }^{3}$ See Demirguc-Kunt, Asli and Edward J. Kane, March 1998, "Deposit Insurance: Issues of Principle, Design and Implementation," A World Bank Research Proposal. The data set and the papers of the research project are available on the project website: http://www.worldbank.org/research/interest/confs/upcoming/deposit insurance/home.htm
} 
The purpose of this paper is twofold: to challenge the wisdom of encouraging countries to adopt deposit insurance without first remedying observable weaknesses in their institutional environment and to buttress this challenge by reviewing cross-country empirical evidence on the effects of deposit insurance. The next section characterizes the data set and uses it to summarize the extent of cross-country differences in deposit insurance design. Section 3 explains why cross-country differences in design are appropriate and that differences in the informational and contracting environments of individual countries are bound to affect the optimal design. Section 4 summarizes empirical evidence on the impact of deposit insurance. Section 5 develops policy implications.

\section{Deposit Insurance Around the World}

Table 1 documents the many ways in which deposit-insurance design varies across countries. ${ }^{4}$ An optimal worldwide blueprint is not likely to be found. For example, account coverage varies from unlimited guarantees to tight coverage limits. On the one hand, Mexico, Turkey and Japan promise 100 percent depositor coverage. However, countries like Chile, Switzerland, and U.K. cover only an amount of deposits that is actually less than their per capita GDP. Also, although many countries cover deposits denominated in foreign currency, most schemes exclude interbank deposits. Besides setting a maximum level of coverage, some countries insist that accountholders "coinsure" a proportion of their deposit balances. Coinsurance provisions are still relatively rare, but are more frequent in recently adopted schemes.

\footnotetext{
4 For the complete database, see Demirgüç-Kunt and Sobaci (forthcoming) which builds on earlier studies by Kyei (1995) and Garcia (1999).
} 
Deposit insurance obligations are typically advance-funded, most commonly from a mixture of government and bank sources. To allow the insurer to build and maintain an appropriate fund of reserves against its loss exposures, in such countries banks are generally assessed an annual premium that is based entirely or in large part on the amount of their insured deposits. Efforts to make these annual premiums sensitive to bank risk exposure have begun in recent years.

Insurance schemes are typically managed in a government agency or in a publicprivate partnership. However, a few countries, such as Switzerland, Germany and Argentina, manage their schemes privately. Finally, in almost all countries, membership is compulsory for chartered banks. The most notable exception is Switzerland.

Table 1 also records the establishment dates of each country's scheme. A number of countries adopted or expanded their deposit insurance scheme during crises. For example, Thailand, Malaysia, and Korea moved to blanket coverage in response to their recent crises. The 1990s saw a rapid spread in transitional countries - perhaps partly motivated by their long-term interest in joining the EU - and in some African countries. Countries that adopted deposit insurance in 1999 are Ecuador, El Salvador, and as part of the Central African Currency Union, Cameroon, Central African Republic, Chad, Equatorial Guinea, Gabon, and Republic of Congo. Most of these new schemes show generous coverage levels. For example, Central African Republic and Chad have coverage ratios that lie between 13 and 15 times their GDP per capita.

Precisely because the range of design features is so extensive, the data set can permit analysts to compare and contrast how well different features work in different circumstances. Section 4 of this paper summarizes the implications of research that uses this database to make inferences about key deposit-insurance issues. 


\section{Deposit Insurance Design: Can One Size Fit All?}

Figure 2 underscores the trend in adopting explicit deposit insurance. The identity of the countries listed in Table 1 clarifies that the use of this policy instrument is growing especially fast in developing countries. Whether this is a healthy trend depends on the balance of deposit insurance costs and benefits in particular countries. In countries whose governments have a strong system for collecting taxes or substantial access to foreign credit, the primary benefit of establishing a deposit insurance scheme is to eliminate the immediate threat of financial panic. Since all countries have a safety net, where rigorous enforcement of coverage ceilings is feasible, deposit insurance can cap the government's future commitments to depositors of insolvent institutions. Similarly, offering deposit insurance may allow a government to negotiate increased rights to intervene in a timely fashion into the affairs of insolvent institutions. Protecting unsophisticated small depositors and helping small banks to compete with large ones are often categorized as secondary benefits.

Besides the budgeted costs of running an insurance enterprise, adopting deposit insurance generates unbudgeted indirect costs. The major indirect cost of deposit insurance comes from its potential to subsidize inefficient types of bank risk-taking. The danger that insurance will induce a willful increase in inappropriate risk-taking is called moral hazard. The increase in risk-taking is described as willful because it responds to the extent that a given scheme undermines pre-existing incentives of depositors to 
monitor and police bank risk-taking. To control taxpayers' exposure to moral hazard, the insurer must involve itself or surrogate parties in monitoring and disciplining banks. The balance of benefits and costs engendered by individual deposit insurance features is bound to vary with the character of insurer loss control and how this loss control interacts with weaknesses in the informational and contracting environments of individual countries.

Kane (2000) emphasizes that controlling bank risk-taking requires transparency and deterrency, and that assuring that an insurer acts efficiently requires accountability to taxpayers for successes and failures. Complete transparency is obtained when institutions disclose information that perfectly and costlessly informs either bank creditors or supervisors about changes in a bank's financial condition and risk-taking. Perfect deterrency describes a situation where individual creditors or supervisors can immediately understand the implications of information flows and can protect themselves completely and costlessly from any adverse consequences. Perfect accountability occurs when taxpayers can identify the actions of government officials and hold them fully responsible for the outcomes their actions engender.

Transparency, deterrency and accountability are dimensions of a country's institutional environment. High readings on these dimensions assure that counterparties in private and public sectors can enforce appropriate bank behavior by evaluating bank activities, disciplining their risk-taking, and resolving their financial difficulties promptly. Around the globe, large differences exist in each of these contracting features. Across countries and cultures, proxies for transparency, deterrency and accountability tend to increase with per capita GDP (Kane, 2000), but other elements of social capital play a role as well. 
Safety nets seek to prevent social costs of financial disruption and government intervention from exceeding the social benefits of damage mitigation. Safety-net design -and deposit insurance arrangements in particular-- must address the particular weaknesses that exist in the institutional environment of individual countries. Recognizing that contracting environments tend to become more diverse as per capita income falls has two consequences. First, it implies that recommending a single combination of "best-practice" design features may generate counterproductive consequences in many developing countries. Second, for countries in which transparency, deterrency and accountability are very weak, implementing an efficient explicit deposit insurance scheme may simply be impossible.

Three central dimensions of every country's deposit-insurance system are: the extent to which it relies on private management and/or private funding; the breadth of its formal and informal coverages; and its susceptibility to hidden risk-shifting by insolvent banks. In moving to a system of explicit guarantees, conscientious government officials must adopt coverage, funding, and managerial structures that efficiently mitigate the particular weaknesses in transparency, deterrency, and accountability that left their country vulnerable to financial crises in the past.

The harder it has been for depositors to observe the economic value of bank capital and the character of bank risk-taking, the more important it becomes for regulators to establish informative protocols for reporting the performance and financial condition of insured banks. If the country's system of corporate governance previously gave depositors few protections against risk shifting, officials must enact special deterrent rights for the insurer. Finally, the less accountability the political system imposes on 
public officials generally, the more accountable deposit-insurance managers must be for accurately measuring the incremental social value their activities produce.

Historically, in environments that combine low transparency with low deterrency, it has made sense to extend stockholder liability for bank losses beyond the amount of paid-in capital in closely held banks (Kane and Wilson, 2001) and to make large depositors and substantial nondeposit creditors effectively coinsure bank losses. In lowaccountability environments, deposit-insurance managers need contractual incentives to optimize the degree of transparency and deterrency that they, minority shareholders, and coinsuring depositors receive. In environments that are low in accountability and transparency, private participation in funding and management can help to create the incentives needed to discipline safety-net loss exposures. To the extent that insurer performance can be measured meaningfully, it is useful to establish a fund of deferred compensation for top managers with the payoffs tied to appropriate measures of depositinsurance performance during their particular term in office.

As transparency, deterrency, and accountability evolve through time, so should the design features of a country's safety net. To maintain efficiency over time, the system must respond to fluctuations in private and government regulators' capacity for valuing institutions, for disciplining risk-taking and resolving insolvencies promptly, and for being appropriately rewarded or chastised for how well they perform these tasks.

Kane (2000) also discusses the dangers of using blanket deposit guarantees as a way of dealing with banking crises. In managing a crisis, the urgency of stopping a panic must not be allowed to over-ride the need to identify hopelessly insolvent institutions and cut off their opportunities to expand their risk-taking. To end a panic efficiently, liquidity must be offered only to potentially solvent institutions. 
Indiscriminately issuing government guarantees and other forms of bailout support rewards bad bankers and penalizes good ones. Because such a policy perverts market discipline and risk-taking incentives and imposes unbooked obligations on the national treasury, it promises new and deeper crises in years to come.

\section{Deposit Insurance: Theory and Empirical Evidence}

An extensive theoretical literature analyzes the benefits and costs of deposit insurance and explores the challenge of balancing these benefits and costs to produce an optimal deposit-insurance system. This literature has been summarized by Kane (2000), Calomiris (1996), and others.

However, cross-country empirical evidence on the efficiency of real-world deposit-insurance systems has been harder to come by. We begin this section by posing four empirical questions whose answers indicate how effective an individual country's deposit-insurance system happens to be. The four questions are:

- How does deposit insurance affect bank stability?

- How does deposit insurance affect market discipline?

- How does deposit insurance impact financial development?

- What role does deposit insurance play in managing crises?

We go on to identify pertinent literature bearing on each question and to review empirical evidence on how the answer to each question varies across different countries and contracting environments.

How does explicit deposit insurance affect bank stability? 
In the midst of a systemic crisis, expanding or firming up depositor guarantees has great appeal to policymakers as a crisis-mitigating device. However, the deferred costs of treating a crisis myopically can be substantial. The best long-run way to incorporate deposit insurance into a country's safety net is a matter of controversy among economists. A classic paper by Diamond and Dybvig (1983) frames deposit insurance as an optimal policy in a contracting environment where limited transparency allows bank stability to be threatened by self-fulfilling depositor runs and runs on solvent banks are depositors' only deterrent instrument for reducing their loss exposure. In Allen and Gale (1998), greater transparency allows runs to be triggered only by an actual deterioration in bank asset quality. In this higher-transparency environment, the optimal safety-net strategy is to use central-bank loans to supply liquidity to the banking system.

Precisely because safety nets are so effective in arresting runs, safety nets generate moral hazard. This moral hazard comes both from banks and their regulators. Opportunistic bankers can exploit weaknesses in supervisory transparency and deterrency by taking inefficient risks and even engaging in fraudulent activity. In practice, regulators and politicians who control the supervisory elements of the safety net often have insufficient incentive to monitor and enforce prudential regulations. Kane (1989) shows that regulatory activity encouraged risk-taking by insured thrift institutions during the U.S. S\&L debacle.

Incentives for risk-shifting and looting by banks decline with bank capital and with transparency, deterrency, and accountability. Transparency and bank capital tend to decline in the face of adverse economic shocks (Merton, 1977 and Calomiris, 1990). Looting often takes the form of bankers making loans to themselves or related parties at 
below-market terms. As a bank's capital becomes exhausted, the costs of corrupt lending fall more and more on the safety net (Akerlof and Romer, 1993).

Economic theory offers a mixed message. On the one hand, credible deposit insurance contributes to financial stability by making depositor runs less likely. On the other hand, unless insured institutions' capital positions and risk-taking are supervised carefully, the insurer will accrue loss exposures that undermine bank stability in the long run. Because deposit-insurance theory embraces good and bad outcomes, it is critical to explore empirical evidence. Demirgüç-Kunt and Detragiache (2000) are the first to use the cross-county database to study the link between deposit insurance and financial crises. They use data from 61 countries for the period 1980-1997 to estimate a model of banking crisis. After controlling for other determinants, they find that the presence of poorly designed explicit deposit insurance tends to increase the likelihood that a country will experience a banking crisis and that this result does not appear to be driven by reverse causality.

Recognizing that the design of explicit deposit insurance varies significantly across countries, Demirgüç -Kunt and Detragiache (DKD) focus on whether and how individual design features mitigate the adverse impact of deposit insurance on bank stability. The regression experiment reproduced in Table 2 shows that deposit insurance causes the most trouble in countries where coverage is extensive, where authorities amass a large fund of explicit reserves and earmark it for insolvency resolution, and where the scheme is administered by government officials rather than the private sector. These findings underscore the importance of confronting squarely the moral hazard that deposit insurance threatens to generate. DKD also show that the contribution of deposit insurance to bank fragility is significant in countries where the institutional environment 
lacks transparency and deterrency, but is not significant in countries whose environment is strong. These findings support the hypothesis that where the contracting environment controls incentive conflict, effective prudential regulation and supervision can offset the adverse incentives created by deposit insurance so that moral hazard need not be worrisome.

Eichengreen and Arteta (2000) find that DKD's deposit insurance evidence is not robust to the twin effects of omitting developed countries from their sample and employing a single-dimensional dummy variable to capture the existence of explicit deposit insurance. This finding is not truly inconsistent with DKD whose results are significant when they incorporate deposit insurance design features and institutional characteristics into their analysis. On average, the more a system embraces features that intensify moral hazard, the more vulnerable it is to banking crisis. ${ }^{5}$

However, DKD only imperfectly control for the other components of the financial safety net, particularly for variation in the quality of regulatory and supervisory enforcement. DKD proxy the quality of regulation and supervision by institutional indicators such as bureaucratic quality, bureaucratic delay, lack of corruption, and the quality of contract enforcement and legal efficiency. Barth, Caprio and Levine (2001) compile a comprehensive data base on regulation and supervision of commercial banks and confirm DKD's findings controlling for variation in the character of government oversight.

Policymakers should view the positive correlation between explicit deposit insurance and banking crises as a wakeup call. Credible deposit insurance allows banks to gather deposits regardless of the risks they take. We would expect a positive 
correlation if deposit insurance greatly reduces monitoring by private parties and replaces it by ineffective regulatory and supervisory discipline. In countries with strong institutions, we would expect most or all of this reduction in depositor monitoring to be compensated by official monitoring, so that the impact of deposit insurance on bank fragility would not prove significant. But is there any direct evidence of the impact of deposit insurance on market discipline? We turn to this issue next.

\section{How does deposit insurance affect market discipline?}

In high-transparency environments, depositors can discipline banks that engage in excessive risk-taking by demanding higher deposit interest rates or by withdrawing their deposits. However, to the extent that deposit insurance reduces the stake that depositors have in monitoring and policing bank capital and loss exposures, it shifts responsibility for controlling bank risk-taking to the regulatory system. Wherever deposit-insurance managers displace more discipline than they exert, bank performance is undermined. To understand this, we must investigate two questions:

- How do depositors exert market discipline?

- How does deposit insurance lessen depositor discipline?

Evidence on market discipline as reflected in bank interest cost comes primarily from U.S. experience. Flannery (1998) surveys research on how the interest cost of uninsured bank deposits and other debt instruments in the U.S. responds to observable measures of default risk. In the U.S., balances in excess of $\$ 100,000$ are not insured.

\footnotetext{
${ }^{5}$ Indeed, Demirguc-Kunt and Detragiache (2000)'s results with a simple dummy are also only significant at
} 
Typically, researchers find that interest rates paid on these partially insured instruments (certificates of deposits, CDs) increase significantly with bank riskiness (Baer and Brewer 1986, Hannan and Hanweck 1988, and Brewer and Mondschean 1994). Linking movements in CD rates to bank-specific news embedded in movements in stock prices, Ellis and Flannery (1992) show that bank CD rates respond generally to market perceptions of bank-specific risks.

Cook and Spellman (1994) find that, even on fully insured deposits, risk premiums at U.S. savings and loan associations (S\&Ls) responded to individualinstitution risk factors in 1987. This sensitivity to risk emerged because the deep economic insolvency of their federal guarantor was becoming clear at that time. These premiums served simultaneously to rein in gambling by aggressive S\&Ls and their insolvent insurer. This evidence indicates that inadequacies in supervision and insurer net worth can reduce the credibility of an insurer's guarantees.

Moving beyond depositor reactions, Flannery and Sorescu (1996) study market yield spreads between uninsured bank debentures and callable treasury bonds. These spreads showed significant sensitivity to bank risk during the years 1989-1991 when the mess was being cleaned up. This was also a time when doubts were emerging about whether the FDIC could or would fully rescue creditors of insolvent bank holding companies. The importance of variation in the credibility of implicit and explicit guarantees is supported in a negative way by the behavior of spreads on bank derivatives in the less stressful era of 1983-1984. Analyzing data from that era, Avery, Belton and Goldberg (1988) and Gorton and Santomero (1990) failed to uncover any risk sensitivity. Apparently, interest costs on insured deposits and uninsured instruments discipline 
depository institutions ever more strongly when doubts arise about the insurer's ability to cover its guarantees. Such doubts are endemic to developing countries and can accelerate quickly.

Evidence on whether the deposit growth of banks is retarded by default risk premiums is available from a wide spectrum of countries and time periods. Gorton and Pennacchi (1990) explain why we should expect deposit growth to slow at a troubled institution. Statistical analysis uncovers similar patterns around the world. MartinezPeria and Schmukler (1998), find that deposits at banks in Argentina, Chile and Mexico respond negatively to risk measures generated from accounting data. They also show that in Chile, where deposit insurance appeared most credible, uninsured depositors were effective monitors of bank risk.

Examining a sample of New York City banks in the 1920s and 1930s, Calomiris and Wilson (1998) show that depositors successfully discriminated among banks on the basis of their riskiness and tended to shift funds to safer havens. Similarly, Kane (1987) reports that when the Ohio Deposit Guarantee Fund (ODGF) fell into crisis in 1985, Ohio depositors removed funds only from ODGF-insured institutions. Park (1995) and Park and Peristiani (1998) show that, during the 1980s, deposit growth at individual U.S. thrifts was negatively related to their estimated probability of default, so that riskier thrifts experienced smaller deposit growth.

Demirgüç-Kunt and Huizinga (DKH, 2000) build a bank-level dataset covering 43 countries over 1990-1997, and study both dimensions of depositor discipline by looking at interest rates and deposit growth. The evidence shows that explicit insurance lowers banks' interest expenses and makes interest payments less sensitive to bank risk and liquidity. However, regardless of the character of a country's safety net, some 
market discipline survives. Consistent with the U.S. evidence on interest sensitivity, the market discipline DKH can observe responds to gaps in coverage, weaknesses in the credibility of the guarantees, and delays and other costs entailed in recovering funds from the guarantor.

DKH particularly focus on how variation in design characteristics affect market discipline. They find that market discipline is stronger in countries with higher levels of institutional development. Nevertheless, even in countries whose institutional development is strong, badly designed deposit insurance curtails market discipline. Setting higher coverage limits, extending coverage to interbank deposits, establishing an ex-ante fund of reserves, funding reserves from government sources, and insisting on public management each displaces market discipline. On the other hand, market discipline is enhanced by coinsurance provisions, covering foreign currency deposits, and establishing private or joint management of the insurance enterprise.

The value deposit insurance offers banks and their creditors can be measured by the reduction it creates in required interest rates. Society pays for increases in the perceived safety of deposits by accepting the administrative costs of supervising banks and the consequences of any net reduction in market discipline. "Correct" pricing through insurance premia could in principle eliminate risk shifting, but such pricing is politically and administratively difficult, especially in developing countries. Leaven (2001) extracts estimates of annual implicit subsidies to banks for a sample of 14 countries from market prices of bank stock. He finds that the cost of deposit insurance is highly country-specific, being highest in countries with low per-capita GDP and poor institutional environments. German banks take very low risks and accrue the smallest gross subsidies from deposit insurance. This reinforces the conclusions reached by Beck 
(2001) in his case study of German deposit insurance. Beck finds that private management, mutual liability and the anti-bankruptcy bias curb risk-taking incentives at German banks. ${ }^{6}$

Such individual-bank data provide direct evidence of the way in which deposit insurance design can affect bank risk-taking incentives. Although deposit insurance displaces market discipline even in advanced countries, the net effect may be improved by strong regulation and supervision. These findings reinforce the evidence on deposit insurance and banking crises. Countries with poor contracting environments are most likely to suffer adverse consequences from deposit insurance.

Some argue that in institutionally underdeveloped countries explicit deposit insurance may have other advantages that offset its negative effects on market discipline and systemic stability. Folkerts-Landau and Lindgren (1998) maintain that the principal benefit of deposit insurance is to provide a risk-free asset to small savers. Critics of this view point out that this benefit may be obtained without destabilization costs by issuing assets such as postal savings or money market funds backed by government debt (Calomiris, 1996, Stiglitz, 1992), or by insisting that banks issuing insured deposits could be constrained to remain "narrow" banks. A second and specifically evolutionary view maintains that in countries with underdeveloped institutions, deposit insurance may be expected to create a launching pad for improving the banking system so that it performs financial intermediation more efficiently. We examine empirical evidence on this hypothesis in the next section.

\section{How Does Deposit Insurance Impact Financial Development?}

\footnotetext{
${ }^{6}$ The first two factors can also explain the good performance of the U.S. scheme for insuring credit unions
} 
Countries adopt deposit insurance for different reasons. However, a common reason is to increase the flow of bank credit by increasing the confidence that the general public has in the formal banking system without having to explicitly raise or expend current fiscal resources. To the extent that deposit insurance bolsters depositors' faith in the stability of the banking system, it may mobilize household savings for use by the financial system. The question is whether or not the funds mobilized go on to support improved patterns of investment and sustainably higher aggregate economic growth.

Recent adopters of deposit insurance have included African and Latin American countries with low levels of financial development. To investigate whether and how explicit deposit insurance contributes to financial development, Cull, Senbet and Sorge (2000) examine time-series data for 58 countries. These authors find that explicit deposit insurance favorably impacts the level of financial activity and its volatility only in the presence of strong institutional development. If deposit-insurance arrangements do not include a regulatory scheme that can overcome weaknesses in the institutional environment, instability is fostered and subsequent financial development is harmed. Examining a cross section of 49 countries, Cecchetti and Krause (2000) show that deposit insurance retards the evolution of nonbank financing mechanisms. Countries with more extensive bank deposit insurance tend to have smaller capital and financial markets and a lower number of publicly traded firms per capita.

Thus, in institutionally weak environments, deposit insurance appears to retard rather than to foster financial development. Cross-country research underscores the longrun danger facing countries that adopt explicit deposit insurance without stopping to repair demonstrable inadequacies in their contracting environments. This evidence

(Kane and Hendershott, 1996). 
amounts to a caution flag for authorities considering whether to adopt deposit insurance. Their decision making process should begin with an audit of the degree of transparency, deterrency, and accountability present in their institutional framework. Good safety-net design does not consist of merely copying what works in developed countries. Good design adapts itself to the need to mitigate problems specific to a country's framework for financial contracting. Officials often act as if institutional audits and country-specific adaptations may be set aside in times of crisis. According to this view, countries whose creditors pressure them to adopt deposit insurance in the midst of a financial crisis have little opportunity to think about longer-term consequences. It is fair to ask whether provision of blanket deposit insurance is of much help in managing crises. Again, we turn to empirical evidence.

\section{What Role Does Deposit Insurance Play in Managing Crises?}

It is common practice to issue blanket guarantees to arrest a banking crisis. Countries adopting this strategy include Sweden (1992), Japan (1996), Thailand (1997), Korea (1997), Malaysia (1998), and Indonesia (1998). More recently, Turkey tried to halt its financial panic by guaranteeing not just bank depositors, but all domestic and foreign nondeposit creditors of Turkish banks.

Advocates of using blanket guarantees to halt a systemic crisis argue that sweeping guarantees can be helpful, even essential, in halting depositors' flight to quality. However, because blanket guarantees create an expectation of their future use in similar circumstances, they undermine market discipline and may prove greatly destabilizing over longer periods. Although some countries have managed to scale back 
formal insurance coverage once a crisis has receded, it is very difficult to scale back informal coverage in a credible manner.

It is clear that a policy of credibly extending blanket guarantees is sufficient to stop a depositor run. However, for governments in developing countries, establishing and subsequently maintaining the credibility of its guarantees is a costly matter. Extensive government guarantees shift accrued losses and loss exposures from bank stakeholders to taxpayers. The fiscal cost of making good on blanket guarantees is an implicit government expenditure that generates an equal amount of implicit government debt. This unbooked spending and unbooked debt subtly undermine the country's foreign-exchange reserves. Hence, in countries whose fiscal capacity is weak, financially sophisticated parties face continuing incentives to move wealth offshore. If this capital flight begins soon enough, blanket guarantees may not work even in the short run without extensive outside support.

Even if successful in stopping an immediate crisis, introducing guarantees to stop a crisis creates the expectation of similar bailouts in future crises. The more frequently this remedy is used and the more enthusiastically it is approved by foreign and multinational institutions, the harder it becomes for banks and their creditors to take seriously post-crisis attempts to roll formal coverages back to less-disruptive levels. Honohan and Klingebiel (2000) analyze the impact of blanket guarantees and other crisismanagement strategies on the ultimate fiscal cost of resolving banking-system distress. Data covering forty crises around the world indicate that unlimited depositor guarantees, open-ended liquidity support, and regulatory forbearance significantly increase the ultimate fiscal cost of resolving a banking crisis. Moreover, these authors find no tradeoff between fiscal costs and the speed of economic recovery. In their sample, depositor 
guarantees and regulatory forbearance failed to significantly reduce either crisis duration or the crisis-induced decline in aggregate real output. Providing liquidity support for insolvent institutions appears to prolong a crisis by destabilizing bank-lending incentives so extensively that healthy adjustments are delayed and additional output loss is generated.

Even in the midst of a crisis, it is inefficient to sacrifice long-term goals to resolve immediate pressures. Efficient crisis management begins with triage. Hopelessly insolvent institutions must be identified and their risk-taking brought under control. Providing open-ended liquidity support to moribund institutions and extending blanket guarantees to their creditors is apt to spawn new and more-virulent crises down the line. Even when conceived entirely as a temporary emergency measure, blanket depositinsurance guarantees engender high fiscal costs. Incurring these costs is unlikely to help the real economy to recover faster from banking crisis or to experience a smaller output loss.

\section{Conclusions and Policy Implications}

The empirical research reviewed here answers two main questions:

- Whether some countries would do well to avoid explicit deposit insurance all together?

- How should deposit-insurance design respond to cross-country differences in transparency, deterrency, and accountability?

Should every country adopt explicit deposit insurance?

Cross-country empirical research on deposit insurance strongly supports the hypothesis that in institutionally weak environments, poorly designed deposit-insurance 
arrangements tend to increase the probability of future banking crises. This finding is statistically robust, in that it emerges using different data sets and two very different research protocols. When researchers compare the incidence of observed banking crises in different countries around the world, countries with poorly designed explicit depositinsurance systems are found to experience more crises. Moreover, the frequency of these crises is worse in countries that have weak contracting environments. When researchers focus instead on bank-level interest costs and deposit growth in different countries, net private and government monitoring of banks proves decisively weaker in poorly designed systems.

The most plausible interpretation of these results is that governments should address weaknesses in their transparency, deterrency, and accountability before adopting explicit deposit insurance schemes. Improving banking regulation and supervision, reforming the legal system such that property rights are protected and contract enforcement is strengthened, upgrading accounting and disclosure rules so that accurate information reaches the markets in a timely fashion exemplify the kinds of institutional reforms that improve incentive structures and limit excess risk-taking.

In poor contracting environments, risk-shifting is magnified because insuranceinduced reductions in private monitoring are intensified by deficiencies in the nature of official monitoring. Banks are tempted to exploit monitoring weakness by issuing insured deposits and using them to finance projects with substantial downside risks. As the expanding value of unbooked guarantees subtly exhausts the fiscal capacity of the government, the fragility of a country's financial system increases. Although government officials have often been led to believe that deposit insurance helps to develop a robust financial system, it cannot do this unless the contracting environment can support it. 
Poor supervision leads banks to lend on positively skewed, but negative present-value projects. Such lending undermines bank solvency, destroys real economic capital, and deters financial development.

Cross-country empirical research verifies the importance of a nation's financialcontracting environment. A country must prepare itself to support explicit deposit insurance in an efficient manner. Governments that are thinking of adopting deposit insurance must recognize that a strong contracting environment is a precondition. Indeed, if a country's contracting environment is not characterized by a reasonable degree of transparency, accountability and deterrency, an explicit deposit insurance scheme is likely to do more harm than good. For countries with weak institutions, adopting explicit deposit insurance promises at best to assist financial development only in the very short run. Over longer periods, it is likely to undermine market discipline, aggravate moral hazard and intensify financial fragility. This policy conclusion is distressingly relevant because many of the countries recently adopting explicit deposit insurance have a demonstrably poor contracting environment.

How should explicit deposit insurance be designed?

Cross-country empirical research offers lessons for countries that have installed or are in the process of adopting explicit deposit-insurance schemes. Even in favorable circumstances, using explicit deposit insurance to increase depositor confidence threatens to heighten financial fragility by reducing the degree of market discipline that banks experience. However, appropriate design features can both control and offset these effects to minimize social costs. 
Empirical research supports the hypothesis that the following features enhance market discipline and reduce moral hazard:

- Credibly low coverage limits per account

- Narrow coverage (e.g., excluding interbank deposits)

- Coinsurance (and alternative private loss-sharing arrangements such as subordinated debt and extended stockholder liability)

- Compulsory membership

- Ex-post funding

- Targeting surviving banks to cover losses (although taxpayers may be asked to assist banks in a truly systemic crisis)

- Private-public joint management

The advantages of credibly limiting insurance coverage and requiring compulsory membership are obvious and not at all controversial. Limiting coverage in a believable way ensures that identifiable groups of private individuals - large depositors, subordinated debtholders or other banks -understand that their funds are inescapably at risk. This exposure to loss gives them an incentive to monitor the behavior of both banks and safety-net managers. Compulsory membership increases the size of the insurance pool and prevents low-risk institutions from selecting out of the system. This means that low-risk, well-managed banks can help officials to monitor and police high-flying competitors.

The preference for ex-post funding and private involvement in insurance design and management is inevitably a harder sell. On the one hand, not having immediate access to a pool of accumulated liquid reserves threatens to delay authorities from dealing with insolvent institutions in a timely manner. However, cross-country evidence indicates that in weak institutional environments the net economic value of depositinsurance reserves is routinely overstated by failing to account for the implicit liabilities 
that weak and insolvent clients implicitly shift onto these reserves. Indeed, an overvalued fund tends to intensify moral hazard by leading depositors and competing institutions to ignore evidence of individual bank insolvencies.

Even if left unfunded, a country's deposit-insurance scheme could still be given immediate access to a credit line either from its national treasury or from reinsurance contracts written with reliable outside insurers. In weak contracting environments, it is useful to assign additional decision-making units, such as the treasury or foreign reinsurers, meaningful responsibility for overseeing design and management decisions. Irrespective of whether net deposit-insurance losses are funded ex ante or ex post, it must be made clear that funds to cover losses will come principally from surviving banks. Otherwise, government backup threatens to reduce market discipline and increase fragility.

Empirical evidence also indicates that involving private parties in managing deposit-insurance arrangements reduces moral hazard and fragility. While private managers can also shirk their duties and even misappropriate funds, stakeholders in any private scheme have strong incentives to monitor and police managerial actions.

Finally, the importance of the research summarized here is to focus attention on the need to identify institutional prerequisites for adopting deposit insurance and to make a concerted effort to get system's design right. Cross-country research does not show that deposit insurance is universally a mistake or that all countries with explicit systems should abandon their scheme at the first opportunity. In countries where the contracting environment is well developed, systemic problems are rare and correlations between design features and crises are weaker and often insignificant. 


\section{References}

Akerlof, George A. and Paul Romer, 1993, "Looting: The Economic Underworld of Bankruptcy for Profit," Brookings Papers on Economic Activity, no. 2, 1-73.

Allen, Franklin, and Douglas Gale, 1998, "Optimal Banking Crises", Journal of Finance, 53 (4), pp. 1245-1284.

Avery, Robert B, Terrence M. Belton and Michael A. Goldberg, 1988, Market discipline in regulating bank risk: new evidence from the capital markets, Journal of Money, Credit, and Banking 20, 597-610.

Baer, Herbert and Elijah Brewer, 1986, Uninsured deposits as a source of market discipline: a new look, Quarterly Journal of Business and Economics 24, 3-20.

Barth, James, Gerard Caprio, and Ross Levine, 2001. "Prudential Regulation and Supervision: What Works and What Doesn't," World Bank mimeo.

Beck, Thorsten, 2001, "Deposit Insurance as a Private Club: The Case of Germany," Quarterly Review of Economic and Finance, forthcoming.

Brewer, Elijah III and Thomas H. Mondschean, 1994, An empirical test of the incentive effects of deposit insurance, Journal of Money, Credit, and Banking 26, 146-164.

Calomiris, Charles W., 1990, “ Is Deposit Insurance Necessary? A Historical Perspective," Journal of Economic History (June), 283-295.

Calomiris, Charles, W., 1996, "Building an Incentive-Compatible Safety Net: Special Problems for Developing Countries", mimeo, Columbia University.

Calomiris, Charles W. and Andrew Powell, 2000, "Can Emerging Market Bank Regulators Establish Credible Discipline? The Case of Argentina," World Bank mimeo.

http://www.worldbank.org/research/interest/confs/upcoming/deposit insurance/home.htm

Calomiris, Charles and Berry Wilson, 1998, Bank Capital and Portfolio Management: The 1930's "Capital Crunch" and Scramble to Shed Risk," NBER Working Paper No. 6649.

Caprio, Gerard and Daniela Klingebiel, 1999, "Episodes of Systemic and Borderline Financial Crises." World Bank, Financial Sector Strategy and Policy Department, Washington D.C.

Cecchetti, Stephen and Stefan Krause, 2000, Deposit Insurance and External Finance, Ohio State University mimeo.

Cook, Douglas O. and Lewis J. Spellman, 1994, "Repudiation risk and restitution costs: 
toward understanding premiums on insured deposits," Journal of Money, Credit, and Banking 26, 439-459.

Cull, Robert, Lemma W. Senbet, and Marco Sorge, 2000, "Deposit Insurance and Financial Development," World Bank mimeo.

http://www.worldbank.org/research/interest/confs/upcoming/deposit insurance/home.htm

Demirguc-Kunt, Asli and Tolga Sobaci, 2001, "Deposit Insurance Around the World: A Database," World Bank Economic Review, forthcoming.

Demirguc-Kunt, Asli and Enrica Detragiache, 2000, "Does Deposit Insurance Increase Banking System Stability? An Empirical Investigation," World Bank mimeo. http://www.worldbank.org/research/interest/confs/upcoming/deposit insurance/home.htm

Demirguc-Kunt, Asli and Harry Huizinga, 2000, “ Market Discipline and Financial Safety Net Design," World Bank mimeo. http://www.worldbank.org/research/interest/confs/upcoming/deposit insurance/home.htm

Diamond, Douglas, and Philip Dybvig, 1983, "Bank Runs, Deposit Insurance, and Liquidity,” Journal of Political Economy, 91 (3), pp. 401-19.

Eichengreen, Barry, and Carlos Arteta, 2000, "Banking Crises in Emerging Markets: Presumptions and Evidence," University of California, Berkeley, mimeo.

Ellis, David M. and Mark J. Flannery, 1992, Does the debt market assess large banks' risk?, Journal of Monetary Economics 30, 481-502.

Flannery, Mark J., 1998, Using market information in prudential bank supervision: a review of the U.S. empirical evidence, Journal of Money, Credit, and Banking 30, 273-305.

Flannery, Mark J. and Sorin M. Sorescu, 1996, Evidence of bank market discipline in subordinated debenture yields: 1983-1991, Journal of Finance 51, 1347-1377.

Folkerts-Landau, David, and Carl-Johan Lindgren, 1998, Toward a Framework for Financial Stability, (Washington, International Monetary Fund).

Garcia, Gillian, 1999, “Deposit Insurance: A Survey of Actual and Best Practices”, IMF Working Paper No. 99/54.

Golembe, Carter H. 1960, “ The Deposit Insurance Legislation of 1933: An Examination of Its Antecedents and Its Purposes," Political Science Quarterly, 75 (2,June): 181-200.

Gorton, G. and G. Pennacchi, 1990, "Financial Intermediaries and Liquidity Creation," Journal of Finance, 45, 49-72.

Gorton, Gary and Athony M. Santomero, 1990, Market discipline and bank subordinated 
debt, Journal of Money, Credit, and Banking 22, 119-128.

Hannan, Timothy H. and Gerald A. Hanweck, 1988, Bank insolvency risk and the market for large certificates of deposit, Journal of Money, Credit, and Banking 20, 203211.

Honohan, Patrick and Daniela Klingebiel, 2000, "Controlling Fiscal Costs of Banking Crises," World Bank mimeo. http://www.worldbank.org/research/interest/confs/upcoming/deposit insurance/home.htm

Kane, Edward J., 1987, Who should learn what from the failure and delayed bailout of the ODGF? in Federal Reserve Bank of Chicago, Proceedings from a Conference on Bank Structure and Competition, 306-326

Kane, Edward J., 1989, The S\&L Insurance Mess: How Did it Happen?, (Washington: Urban Institute Press).

Kane, Edward J.,1995, “ Three Paradigms for the Role of Capitalization Requirements in Insured Financial Institutions,” Journal of Banking and Finance, 19, 431-459.

Kane, Edward J., 2000, Designing Financial Safety Nets to Fit Country Circumstances," World Bank mimeo. http://www.worldbank.org/research/interest/confs/upcoming/deposit insurance/home.htm

Kane, Edward J., and Robert H. Hendershott, 1996. "The Federal Deposit Insurance Fund that Didn't Put a Bite on U.S. Taxpayers," Journal of Banking and Finance 20(September), pp. 1305-1327.

Kane, Edward J., and Berry Wilson, 2001. "Evidence of Safety Net Support During Economic Development in Canada, the U.K., and the U.S." unpublished working paper, Boston College.

Kyei, Alexander, "Deposit Protection Arrangements: A Survey", IMF Working Paper No. 95/134.

Laeven, Luc, 2001, International Evidence on the Cost of Deposit Insurance, Quarterly Review of Economics and Finance, forthcoming.

Martinez Peria, Maria Soledad and Sergio L. Schmukler, 1999, Do depositors punish banks for "bad" behavior?, Policy Research Paper no. 2058, World Bank, Washington, D.C. (forthcoming Journal of Finance) http://www.worldbank.org/research/interest/confs/upcoming/deposit insurance/home.htm

Merton, Robert C., 1977, "An Analytic Derivation of the Cost of Deposit Insurance Loan Guarantees: An Application of Modern Option Pricing Theory," Journal of Banking and Finance (June), 3-11. 
Mishkin, Fredrick, 1996, "Understanding Financial Crises: A Developing Country Perspective" in the proceedings of the Annual World Bank Conference on Development Economics.

Park, Sangkyun, 1995, Market discipline by depositors: evidence from reduced-form equations, Quarterly Review of Economics and Finance 35, 497-514.

Park, Sangkyun and Stavros Peristiani, 1998, Market discipline by thrift depositors, Journal of Money, Credit, and Banking 30, 347-364.

Stiglitz, Joseph E., 1992, "S\&L Bailout", in James R. Barth and R. Dan Brunbaugh Jr. (Eds.),The Reform of Federal Deposit Insurance, (New York, HarperBusiness).

World Bank, 2001, Finance for Growth: Policy Choices in a Volatile World, Policy Research Report, Washington D.C. 
Figure 1.

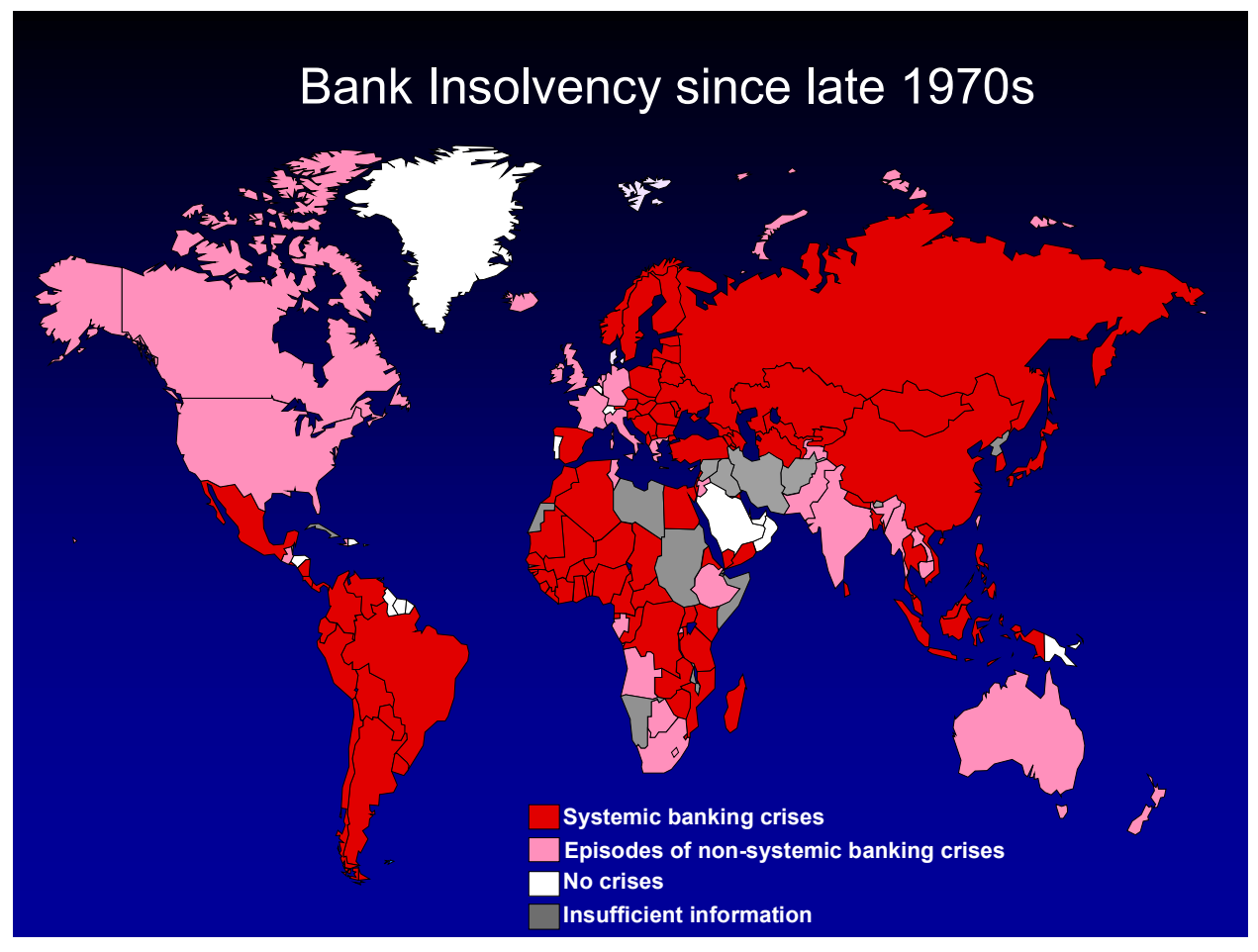

Source: Caprio and Klingebiel (1999). 
Figure 2. Number of explicit deposit insurance systems in existence, 1934-99 Cumulative frequency of explicit DI systems established

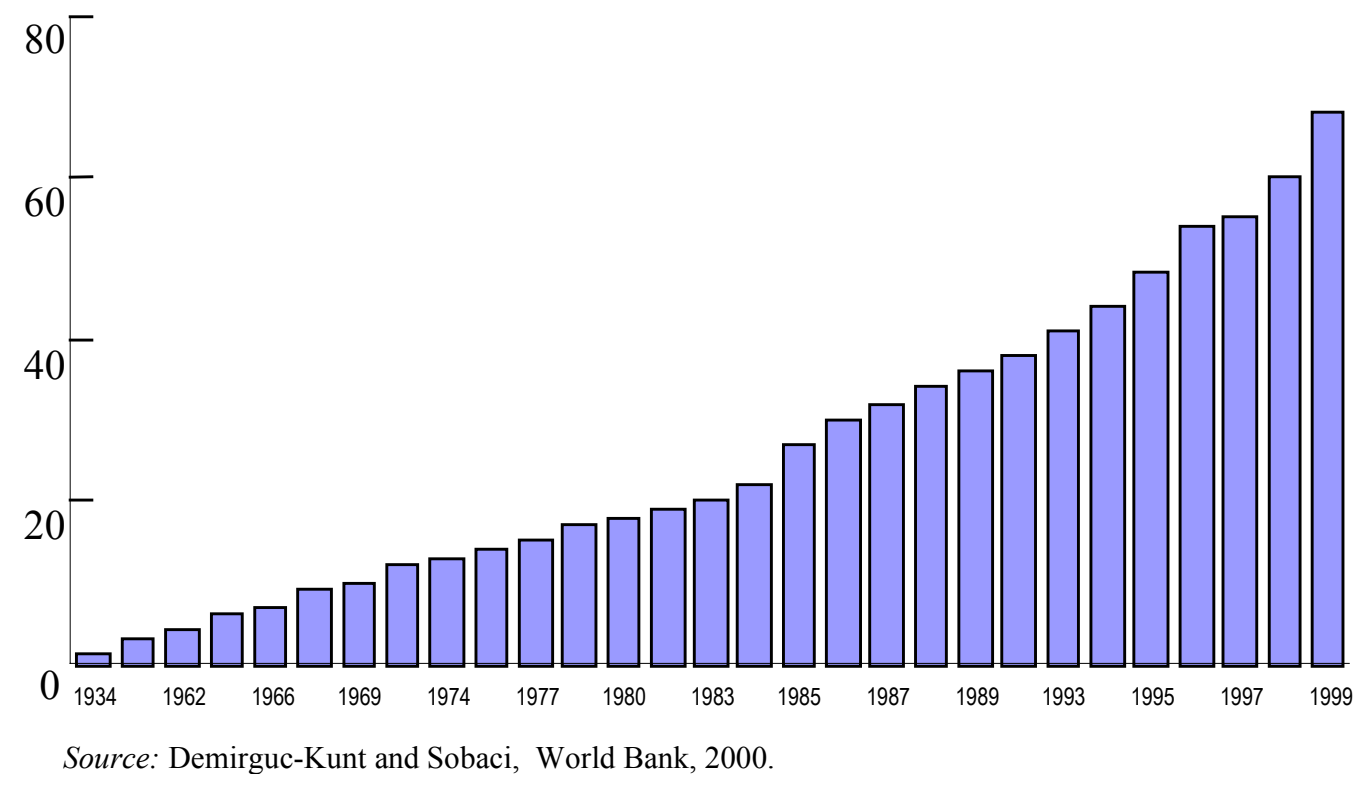


Table 1. Deposit Insurance Around the World : Design of Explicit Deposit Insurance

\begin{tabular}{|c|c|c|c|c|c|c|c|c|}
\hline Countries & $\begin{array}{l}\text { Date Enacted } \\
\text { / Revised }\end{array}$ & $\begin{array}{c}\text { Coverage Limits } \\
\text { USS or ECU }\end{array}$ & $\begin{array}{l}\text { Coverage } \\
\text { Ratios } \\
\text { Limit/gdp } \\
\text { per capita }\end{array}$ & $\begin{array}{r}\text { Co- } \\
\text { insurance } \\
\mathrm{Y}= \\
\mathrm{N}=\end{array}$ & $\begin{array}{l}\text { Permanent } \\
\text { Fund } \\
\text { Yes } \\
\text { No }\end{array}$ & $\begin{array}{l}\text { Annual Premiums } \\
\% \text { of insured deposits } \\
\text { unless otherwise noted }\end{array}$ & $\begin{array}{l}\text { Source of } \\
\text { Funding } \\
\qquad \mathrm{P}=\text { Pri }\end{array}$ & $\begin{array}{l}\text { Administration } \\
\text { e, } \mathrm{O}=\text { Official } \\
=\text { Joint }\end{array}$ \\
\hline Argentina & $\begin{array}{c}1979 / 1992 / \\
1995\end{array}$ & 30000 & 3 & $\mathrm{~N}$ & $\mathrm{Y}$ & $\begin{array}{l}\text { risk-based, } 0.36 \text { to } \\
0.72\end{array}$ & $\mathrm{P}$ & $\mathrm{P}$ \\
\hline Austria & $1979 / 1996$ & $\begin{array}{l}\$ 24,075 \text { but coinsurance } \\
\text { for businesses }\end{array}$ & 1 & $\mathrm{Y}$ & $\mathrm{N}$ & pro rata, expost & $\mathrm{J}$ & $\mathrm{P}$ \\
\hline Bahrain & 1993 & 5640 & 1 & $\mathrm{~N}$ & $\mathrm{~N}$ & ex post & $\mathrm{P}$ & $\mathrm{J}$ \\
\hline Bangladesh & 1984 & 2123 & 6 & $\mathrm{~N}$ & $\mathrm{Y}$ & 0.005 & $\mathrm{~J}$ & $\mathrm{O}$ \\
\hline Belgium & $1974 / 1995$ & $\begin{array}{l}15,000 \text { ECU until year } \\
2000\end{array}$ & 1 & $\mathrm{~N}$ & $\mathrm{Y}$ & $\begin{array}{l}0.02+0.04 \text { of insured } \\
\text { liabilities }\end{array}$ & $\mathrm{J}$ & $\mathrm{J}$ \\
\hline Brazil & 1995 & 17000 & 4 & $\mathrm{~N}$ & $\mathrm{Y}$ & 0.3 & $\mathrm{P}$ & $\mathrm{P}$ \\
\hline Bulgaria & 1995 & 1784 & 1 & $\mathrm{~N}$ & $\mathrm{Y}$ & risk based to 0.5 & $\mathrm{~J}$ & $\mathrm{~J}$ \\
\hline Cameroon & 1999 & 5336 & 9 & $\mathrm{~N}$ & $\mathrm{Y}$ & $\begin{array}{l}\text { risk based: } 0.15 \% \text { of } \\
\text { deposits }+0.5 \% \text { of net } \\
\text { non-performing loans }\end{array}$ & $\mathrm{J}$ & $\mathrm{J}$ \\
\hline Canada & 1967 & 40770 & 2 & $\mathrm{~N}$ & $\mathrm{Y}$ & $0.33 \max$ & $\mathrm{J}$ & $\mathrm{O}$ \\
\hline $\begin{array}{l}\text { Central } \\
\text { African Rep. }\end{array}$ & 1999 & 3557 & 13 & $\mathrm{~N}$ & $\mathrm{Y}$ & $\begin{array}{l}\text { risk based: } 0.15 \% \text { of } \\
\text { deposits }+0.5 \% \text { of net } \\
\text { non-performing loans }\end{array}$ & $\mathrm{J}$ & $\mathrm{J}$ \\
\hline Chad & 1999 & 3557 & 15 & $\mathrm{~N}$ & $\mathrm{Y}$ & $\begin{array}{l}\text { risk based: } 0.15 \% \text { of } \\
\text { deposits }+0.5 \% \text { of net } \\
\text { non-performing loans }\end{array}$ & $\mathrm{J}$ & $\mathrm{J}$ \\
\hline Chile & 1986 & $\begin{array}{l}\text { demand deposits in full } \\
\text { and } 90 \% \text { coinsurance to } \\
\text { UF } 120 \text { of } \$ 3,600 \text { for } \\
\text { savings deposits }\end{array}$ & 1 & $\mathrm{Y}$ & $\mathrm{N}$ & none & $\mathrm{O}$ & $\mathrm{O}$ \\
\hline Colombia & 1985 & $\begin{array}{l}\text { in full untill } 2001 \text {, then } \\
\text { coinsurance to } \$ 5,500\end{array}$ & 2 & $\mathrm{Y}$ & $\mathrm{Y}$ & 0.3 & $\mathrm{P}$ & $\mathrm{O}$ \\
\hline Croatia & 1997 & 15300 & 3 & $\mathrm{~N}$ & $\mathrm{Y}$ & 0.8 & $\mathrm{~J}$ & $\mathrm{~J}$ \\
\hline Czech Rep. & 1994 & coinsurance to $\$ 11,756$ & 2 & $\mathrm{Y}$ & $\mathrm{Y}$ & $\begin{array}{l}\text { commercial banks } 0.5 \text {, } \\
\text { savings banks } 0.1\end{array}$ & $\mathrm{~J}$ & $\mathrm{O}$ \\
\hline Denmark & $1988 / 1998$ & $20000 \mathrm{ECU}$ & 1 & $\mathrm{~N}$ & $\mathrm{Y}$ & 0.2 (maximum) & $\mathrm{J}$ & $\mathrm{J}$ \\
\hline $\begin{array}{l}\text { Dominican } \\
\text { Republic }\end{array}$ & 1962 & coinsurance to $\$ 13,000$ & 7 & $\mathrm{Y}$ & $\mathrm{Y}$ & 0.1875 & $\mathrm{~J}$ & $\mathrm{~J}$ \\
\hline Ecuador & 1999 & in full to year 2001 & & $\mathrm{~N}$ & Y & 0.65 & n.a. & $\mathrm{O}$ \\
\hline El Salvador & 1999 & 4720 & 2 & $\mathrm{~N}$ & $\mathrm{Y}$ & risk-based, 0.1 to 0.3 & $\mathrm{~J}$ & $\mathrm{O}$ \\
\hline $\begin{array}{l}\text { Equatorial } \\
\text { Guinea }\end{array}$ & 1999 & 3557 & 3 & $\mathrm{~N}$ & $\mathrm{Y}$ & $\begin{array}{l}\text { risk based: } 0.15 \% \text { of } \\
\text { deposits }+0.5 \% \text { of net } \\
\text { non-performing loans }\end{array}$ & $\mathrm{J}$ & $\mathrm{J}$ \\
\hline Estonia & 1998 & $\begin{array}{l}\text { coinsurance } 90 \% \text { of } \\
\$ 1383 \text {, but } 20,000 \text { ECU } \\
\text { in year } 2010\end{array}$ & 0 & $\mathrm{Y}$ & $\mathrm{Y}$ & 0.5 (maximum) & $\mathrm{J}$ & $\mathrm{J}$ \\
\hline Finland & $\begin{array}{c}1969 / 1992 / \\
1998\end{array}$ & 29435 & 1 & $\mathrm{~N}$ & $\mathrm{Y}$ & risk based: 0.05 to 0.3 & $\mathrm{~J}$ & $\mathrm{P}$ \\
\hline France & $1980 / 1995$ & 65387 & 3 & $\mathrm{~N}$ & $\mathrm{~N}$ & on demand but limited & $\mathrm{P}$ & $\mathrm{P}$ \\
\hline Gabon & 1999 & 5336 & 1 & $\mathrm{~N}$ & $\mathrm{Y}$ & $\begin{array}{l}\text { risk based: } 0.15 \% \\
\text { deposits }+0.5 \% \text { net } \\
\text { non-performing loans }\end{array}$ & $\mathrm{J}$ & $\mathrm{J}$ \\
\hline Germany & $\begin{array}{c}1966 / 1969 / \\
1998\end{array}$ & $\begin{array}{l}\text { private: } 30 \% \text { of capital; } \\
\text { official coinsurance } 90 \% \\
\text { to } 20000 \mathrm{ECU}\end{array}$ & 1 & $\mathrm{Y}$ & $\mathrm{Y}$ & $\begin{array}{l}\text { official is } 0.03 \text { but can } \\
\text { be doubled }\end{array}$ & $\mathrm{P}$ & $\mathrm{P}$ \\
\hline Gibraltar & 1998 & $\begin{array}{l}\text { lesser of } 90 \% \text { coinsurance } \\
\text { ECU }\end{array}$ & or 20,000 & $\mathrm{Y}$ & $\mathrm{N}$ & $\begin{array}{l}\text { administrative } \\
\text { expenses and expost } \\
\text { contributions }\end{array}$ & $\mathrm{P}$ & $\mathrm{J}$ \\
\hline Greece & $1993 / 1995$ & $20,000 \mathrm{ECU}$ & 2 & $\mathrm{~N}$ & $\mathrm{Y}$ & $\begin{array}{l}\text { decreasing by size: } \\
1.250 \text { to } 0.025\end{array}$ & $\mathrm{P}$ & $\mathrm{J}$ \\
\hline Hungary & 1993 & $4,165 \mathrm{ECU}$ or $\$ 4,564$ & 1 & $\mathrm{~N}$ & $\mathrm{Y}$ & risk based to 0.3 & $\mathrm{~J}$ & $\mathrm{~J}$ \\
\hline Iceland & $1985 / 1996$ & $20,000 \mathrm{ECU}$ & 1 & $\mathrm{Y}$ & $\mathrm{Y}$ & 0.15 & $\mathrm{P}$ & $\mathrm{O}$ \\
\hline India & 1961 & 2355 & 6 & $\mathrm{~N}$ & $\mathrm{Y}$ & 0.05 & $\mathrm{~J}$ & $\mathrm{O}$ \\
\hline Indonesia & 1998 & Blanket guarantee & & & & & & \\
\hline Ireland & $1989 / 1995$ & $\begin{array}{l}\text { coinsurance } 90 \% \text { to } \\
15,000 \mathrm{ECU}\end{array}$ & 1 & $\mathrm{Y}$ & $\mathrm{Y}$ & 0.2 & $\mathrm{P}$ & $\mathrm{O}$ \\
\hline Italy & $1987 / 1996$ & 125000 & 6 & $\mathrm{~N}$ & $\mathrm{~N}$ & $\begin{array}{l}\text { risk adj., expost } 0.4 \text { to } \\
0.8 \text { of protected funds }\end{array}$ & $\mathrm{J}$ & $\mathrm{J}$ \\
\hline Jamaica & 1998 & 5512 & 2 & $\mathrm{~N}$ & $\mathrm{Y}$ & 0.1 & $\mathrm{~J}$ & $\mathrm{O}$ \\
\hline
\end{tabular}




\begin{tabular}{|c|c|c|c|c|c|c|c|c|}
\hline Countries & $\begin{array}{l}\text { Date Enacted } \\
\text { / Revised }\end{array}$ & Coverage Limits & $\begin{array}{c}\text { Coverage } \\
\text { Ratios }\end{array}$ & $\begin{array}{c}\text { Co- } \\
\text { insurance }\end{array}$ & $\begin{array}{c}\text { Permanent } \\
\text { Fund }\end{array}$ & Annual Premiums & $\begin{array}{c}\text { Source of } \\
\text { Funding }\end{array}$ & Administration \\
\hline Japan & 1971 & $\$ 71,000$, but in full until & March 2001 & $\mathrm{~N}$ & $\mathrm{Y}$ & $0.0048+0.036$ & $\mathrm{~J}$ & $\mathrm{~J}$ \\
\hline Kenya & 1985 & 1750 & 5 & $\mathrm{~N}$ & $\mathrm{Y}$ & 0.15 & $\mathrm{~J}$ & $\mathrm{O}$ \\
\hline Korea & 1996 & $\begin{array}{l}\$ 14,600, \text { but in full until } \\
2000\end{array}$ & the year & $\mathrm{N}$ & $\mathrm{Y}$ & 0.05 & $\mathrm{~J}$ & $\mathrm{O}$ \\
\hline Latvia & 1998 & $\$ 830$ until year 2000 & 0 & $\mathrm{~N}$ & $\mathrm{Y}$ & 0.3 & $\mathrm{~J}$ & $\mathrm{O}$ \\
\hline Lebanon & 1967 & 3300 & 1 & $\mathrm{~N}$ & $\mathrm{Y}$ & 0.05 & $\mathrm{~J}$ & $\mathrm{~J}$ \\
\hline Lithuania & 1996 & $\$ 6,250$ then coinsurance & 2 & $\mathrm{Y}$ & $\mathrm{Y}$ & 1.5 & $\mathrm{~J}$ & $\mathrm{O}$ \\
\hline Luxembourg & 1989 & $\begin{array}{l}\text { coinsurance } 90 \% \text { to } \\
\text { ECU } 15000 \text { thru } 1999 \text {, } \\
\text { then to ECU } 20000\end{array}$ & 0 & $\mathrm{Y}$ & $\mathrm{N}$ & ex post & $\mathrm{P}$ & $\mathrm{P}$ \\
\hline Macedonia & 1996 & $\begin{array}{l}\text { coinsurance } 75 \% \text { to } \\
\$ 183\end{array}$ & 0 & $\mathrm{Y}$ & $\mathrm{Y}$ & $\begin{array}{l}1.5 \%, \text { risk-based } 1 \% \\
\text { to } 5 \%\end{array}$ & $\mathrm{~J}$ & $\mathrm{~J}$ \\
\hline Malaysia & 1998 & Blanket guarantee & & & & & & \\
\hline $\begin{array}{l}\text { Marshall } \\
\text { Islands }\end{array}$ & 1975 & 100000 & & $\mathrm{~N}$ & $\mathrm{Y}$ & $\begin{array}{l}\text { risk-based, } 0.00 \text { to } \\
0.27\end{array}$ & $\mathrm{P}$ & $\mathrm{O}$ \\
\hline Mexico & $1986 / 1990$ & $\begin{array}{l}\text { in full except subordinate } \\
2005\end{array}$ & ed debt until & $\mathrm{N}$ & Y & $\begin{array}{l}0.3(\max 0.5) \text { plus } 0.7 \\
\text { as needed }\end{array}$ & $\mathrm{J}$ & $\mathrm{O}$ \\
\hline Micronesia & 1963 & 100000 & & $\mathrm{~N}$ & $\mathrm{Y}$ & $\begin{array}{l}\text { risk-based, } 0.00 \text { to } \\
0.27\end{array}$ & $\mathrm{P}$ & $\mathrm{O}$ \\
\hline Netherlands & $1979 / 1995$ & $20,000 \mathrm{ECU}$ & 1 & $\mathrm{~N}$ & $\mathrm{~N}$ & expost & $\mathrm{J}$ & $\mathrm{O}$ \\
\hline Nigeria & $1988 / 1989$ & $\begin{array}{l}\text { \$588(at market } \\
\text { exchange rate), } \$ 2435 \\
\text { (at official exchange } \\
\text { rate) }\end{array}$ & 2 & $\mathrm{~N}$ & $\mathrm{Y}$ & 0.9375 & $\mathrm{~J}$ & $\mathrm{O}$ \\
\hline Norway & $1961 / 1997$ & 260800 & 8 & $\mathrm{~N}$ & $\mathrm{Y}$ & $\begin{array}{l}0.005 \text { of assets and } \\
0.01 \text { of total deposits }\end{array}$ & $\mathrm{J}$ & $\mathrm{P}$ \\
\hline Oman & 1995 & $\begin{array}{l}\text { coinsurance } 75 \% \text { to } \\
\$ 52,630\end{array}$ & 9 & Y & $\mathrm{Y}$ & 0.02 & $\mathrm{~J}$ & $\mathrm{O}$ \\
\hline Peru & 1992 & 21160 & 9 & $\mathrm{~N}$ & $\mathrm{Y}$ & $\begin{array}{l}\text { risk-based from } 0.65 \\
\text { to } 1.45\end{array}$ & $\mathrm{~J}$ & $\mathrm{~J}$ \\
\hline Philippines & 1963 & 2375 & 3 & $\mathrm{~N}$ & Y & 0.2 & $\mathrm{~J}$ & $\mathrm{O}$ \\
\hline Poland & 1995 & $\begin{array}{l}1,000 \mathrm{ECU}, \text { then } 90 \% \\
\text { coinsurance for the next } \\
4,000 \mathrm{ECU}\end{array}$ & 0 & $\mathrm{Y}$ & $\mathrm{Y}$ & not more than 0.4 & $\mathrm{~J}$ & $\mathrm{O}$ \\
\hline Portugal & $1992 / 1995$ & $\begin{array}{l}15,000 \mathrm{ECU}, \\
\text { coinsurance to } 45,000 \\
\text { ECU }\end{array}$ & 1 & $\mathrm{Y}$ & $\mathrm{Y}$ & $\begin{array}{l}\text { risk-based, } 0.08 \text { to } \\
0.12+\text { more in } \\
\text { emergencies }\end{array}$ & $\mathrm{J}$ & $\mathrm{O}$ \\
\hline $\begin{array}{l}\text { Republic of } \\
\text { Congo }\end{array}$ & 1999 & 3557 & 5 & $\mathrm{~N}$ & $\mathrm{Y}$ & $\begin{array}{l}\text { risk based: } 0.15 \% \text { of } \\
\text { deposits }+0.5 \% \text { of net } \\
\text { non-performing loans }\end{array}$ & $\mathrm{J}$ & $\mathrm{J}$ \\
\hline Romania & 1996 & 3600 & 2 & $\mathrm{~N}$ & $\mathrm{Y}$ & risk-based: 0.3 to 0.6 & $\mathrm{~J}$ & $\mathrm{~J}$ \\
\hline $\begin{array}{l}\text { Slovak } \\
\text { Republic }\end{array}$ & 1996 & 7900 & 2 & $\mathrm{~N}$ & $\mathrm{Y}$ & 0.1 to 0.3 for banks & $\mathrm{J}$ & $\mathrm{J}$ \\
\hline Spain & $1977 / 1996$ & $\begin{array}{l}15,000 \text { ECU through } \\
1999, \text { then } 20,000 \mathrm{ECU}\end{array}$ & 1 & $\mathrm{~N}$ & $\mathrm{Y}$ & maximum of 0.2 & $\mathrm{~J}$ & $\mathrm{~J}$ \\
\hline Sri Lanka & 1987 & 1470 & 2 & $\mathrm{~N}$ & $\mathrm{Y}$ & 0.15 & $\mathrm{~J}$ & $\mathrm{O}$ \\
\hline Sweden & 1996 & 28,663 ECU, $\$ 31,412$ & 1 & $\mathrm{~N}$ & $\mathrm{Y}$ & $\begin{array}{l}\text { risk-based, } 0.5 \text { now, } \\
0.1 \text { later (future date is } \\
\text { not available) }\end{array}$ & $\mathrm{J}$ & $\mathrm{O}$ \\
\hline Switzerland & $1984 / 1993$ & 19700 & 1 & $\mathrm{~N}$ & $\mathrm{~N}$ & on demand & $\mathrm{P}$ & $\mathrm{P}$ \\
\hline Taiwan & 1985 & 38500 & 3 & $\mathrm{~N}$ & $\mathrm{Y}$ & 0.015 & $\mathrm{~J}$ & $\mathrm{O}$ \\
\hline Tanzania & 1994 & 376 & 2 & $\mathrm{~N}$ & $\mathrm{Y}$ & 0.1 & $\mathrm{~J}$ & $\mathrm{P}$ \\
\hline Thailand & 1997 & Blanket guarantee & & & & & & \\
\hline $\begin{array}{l}\text { Trinidad \& } \\
\text { Tobago }\end{array}$ & 1986 & 7957 & 2 & $\mathrm{~N}$ & $\mathrm{Y}$ & 0.2 & $\mathrm{~J}$ & $\mathrm{O}$ \\
\hline Turkey & 1983 & in full & & $\mathrm{N}$ & $\mathrm{Y}$ & risk-based 1.0 to 1.2 & $\mathrm{~J}$ & $\mathrm{O}$ \\
\hline Uganda & 1994 & 2310 & 8 & $\mathrm{~N}$ & $\mathrm{Y}$ & 0.2 & $\mathrm{~J}$ & $\mathrm{O}$ \\
\hline Ukraine & 1998 & 250 & 0 & $\mathrm{~N}$ & $\mathrm{Y}$ & $\begin{array}{l}0.5 \text { plus special } \\
\text { charges }\end{array}$ & $\mathrm{J}$ & $\mathrm{O}$ \\
\hline $\begin{array}{l}\text { United } \\
\text { Kingdom }\end{array}$ & $1982 / 1995$ & $\begin{array}{l}\text { larger of } 90 \% \\
\text { coinsurance to } \$ 33,333 \\
\text { or } 22,222 \mathrm{ECU}\end{array}$ & 1 & $\mathrm{Y}$ & $\mathrm{N}$ & on demand & $\mathrm{P}$ & $\mathrm{P}$ \\
\hline United States & $1934 / 1991$ & 100000 & 3 & $\mathrm{~N}$ & $\mathrm{Y}$ & $\begin{array}{l}\text { risk-based, } 0.00 \text { to } \\
0.27\end{array}$ & $\mathrm{~J}$ & $\mathrm{O}$ \\
\hline Venezuela & 1985 & 7309 & 2 & $\mathrm{~N}$ & $\mathrm{Y}$ & 2 & $\mathrm{~J}$ & $\mathrm{O}$ \\
\hline
\end{tabular}

Source: Demirguc-Kunt and Sobaci, "Deposit Insurance Around the World: A Database," World Bank Economic Review, forthcoming. Full data base available at: http://www.worldbank.org/research/interest/confs/upcoming/deposit insurance/home.htm 


\section{Table 2. Deposit Insurance Design and Banking Crises}

The dependent variable is a crisis dummy which takes the value one if there is a crisis and the value zero otherwise. A logit probability model is estimated. Variables are defined as follows: Explicit coverage limit takes the value 0 if implicit insurance but equals coverage limit divided by deposits per capita lagged one period. Funding variable takes the value 0 if implicit insurance, 1 if explicit insurance with no fund, and 2 if explicit insurance with deposit insurance fund. Management variables take the value 1 if private, joint, or official management and zero otherwise, respectively. The moral hazard index is the first principal component of deposit insurance design features: coinsurance, coverage, scope of coverage, type of funding, source of funding, management, and membership. Regression also includes the following control variables that are not reported below: growth, change in terms of trade, real interest rates, inflation, M2/reserves, depreciation, past credit growth, and gdp per capita. Standard errors are given in parentheses. Source: Demirguc-Kunt and Detragiache, 2000.

$\begin{array}{ll}\text { Explicit Coverage } & .019 * * * \\ \text { Limit } & (.006)\end{array}$

Funding

Official Mgmt.

Joint Mgmt.

Private Mgmt.

Moral Hazard

$(.881)$

Index

$.161 * *$

No. of Crises 34

No. of Obs. $\quad 827$

$\%$ correct 78

$\%$ crisis correct $\quad 71$

Model Chi Sq. 47.03***

257

40

898

75

68

$52.30 * * *$

295
(.074)

39

869

75

64

$50.32 * * *$

292
40

898

78

65

$52.06^{* * *}$ 295

** and *** indicate significance at levels of 5 and 1 percent respectively. 